\title{
ТЕОРЕТИЧНІ ЗАСАДИ ФОРМУВАННЯ КОНКУРЕНТОСПРОМОЖНОСТІ Й КОНКУРЕНТНИХ ПЕРЕВАГ ПІДПРИЄМСТВ СІЛЬСЬКОГО ЗЕЛЕНОГО ТУРИЗМУ
}

\author{
Адамчик Олександр Олександрович \\ аспірант \\ Херсонський державний аграрний університет (м. Херсон, Україна)
}

\begin{abstract}
У статті здійснено визначення змісту категорії конкурентоспроможності та встановлено ії особливості щодо підприємств сільського зеленого туризму. Встановлено, що вони функиіонують не стільки в умовах внутрішньогалузевої, але стільки міжгалузевої конкуренції. Для українського села більш традиційним і типовим є функціонування будь-яких за розмірами сільськогосподарських підприємств, які приносять прибутки практично за будь-яких умов на засадах диверсифікації виробниитва. Виявлено, що за таких обставин безумовно наявні внутрішні та зовнішні конкурентні переваги підприємств сільського зеленого туризму повинні мати додаткову підтримку сільських громад, бюджетні та податкові преференції й інші фрорми та інструменти державної підтримки. Це дозволить зміцнити їх конкурентні позиції з метою не тільки отримання прибутків і задоволення потреб споживачів у відпочинку, але й збільшення зайнятості та рівня життя сільських жителів, зменшення виробничого навантаження на довкілля та вирішення екологічних проблем сільських територій, прискорення розвитку підприємств суміжних галузей та видів діяльності.
\end{abstract}

Ключові слова: підприємства, агрооселі, сільський зелений туризм, конкуренція, конкурентоспроможність, конкурентні переваги, сільське господарство, державна підтримка, формування, сільські території, управління, теоретичні заcadu.

DOI: https://doi.org/10.32845/bsnau.2019.4.17

Постановка проблеми. У сучасній період обмежень міжнародних пересувань громадян для економіки України особливого значення набуває підвищення конкурентоспроможності підприємств сільського зеленого туризму. Вона розглядається як основний чинник забезпечення їх ефективної діяльності та стійкого розвитку на тривалу перспективу. На галузь туризму сьогодні припадає майже 6,0\% світового валового продукту, 7,0\% світових інвестицій, кожне 16-те робоче місце та 11,0\% світових споживчих витрат.

Саме тому туризм доцільно назвати міжгалузевою сферою економіки, яка охоплює не тільки засоби розміщення, але й транспорт, зв'язок, індустрію харчування, розваг і багато іншого. Ця сффера позитивно впливає на країни та їх розвиток. Актуальність проблеми підвищення конкурентоспроможності підприємств сільського зеленого туризму обумовлюється ще і тим, що країни пострадянського простору, в тому числі й Україна, посідають останні місця за рівнем його розвитку як альтернативного виду діяльності щодо сільського господарства як надзвичайно еколого- та енергозатратного для суспільства. Тому питання ії забезпечення на всіх ієрархічних рівнях управління потребують системних розробок та вирішення.

Аналіз останніх досліджень і публікацій. Проблеми конкурентоспроможності, конкуренції підприємств вивчалися

в працях багатьох зарубіжних та вітчизняних вчених, зокрема І. Ансофффа, М.І. Гельванівського, А. Дайана, П. Друкера, Ж. Ламбена, М. Мескона, В. Ойкена, М. Портера, А.Р. Сафіулліна, Р.А. Фатхутдінова, Ф. Хайека, Д. Харрінгтона, Й. Шумпетера, А.Ю. Юданова та ін. Проблемам економіки і управління розвитком підприємств сільського зеленого туризму присвячені роботи В. Азара, А. Александрової, Р. Батлера, I. Балабанова, М. Ігнатенка, К. Купера, Л. Мармуль, В. Пеньковського, Д. Пірса, І. Романюк, Д. Флетчера, Н. Чорненької та ін.

Цілі статті полягають у здійснені визначення змісту категорії конкурентоспроможності та встановлені її особливостей щодо підприємств сільського зеленого туризму.

Виклад основного матеріалу. Конкурентоспроможність підприємств сільського зеленого туризму є складним та багатогранним поняттям. Це пояснюється не тільки ї особливими соціально-економічними й екологічними функціями, але й мотивами організації та функціонування, напрямами діяльності та сукупністю надаваних послуг, присутністю суб'єктивних вражень, отже й їх оцінок споживачами. Проте загалом ії зміст у загальних рисах співпадає з тим, що характерний для інших суб'єктів господарювання. У табл. 1 наведені деякі з визначень поняття «конкурентоспроможність підприємства», що пропонують зарубіжні та вітчизняні автори.

Визначення науковцями поняття «конкурентоспроможність підприємства»

Таблиця 1

\begin{tabular}{|c|l|}
\hline Автори & \multicolumn{1}{|c|}{ Визначення } \\
\hline А. Уінт [1] & $\begin{array}{l}\text { Можливість підприємств отримувати прибутки вище середнього рівня на ринку, де діють як вітчизняні, } \\
\text { так і іноземні конкуренти. }\end{array}$ \\
\hline Г.Л. Азоєв [2] & $\begin{array}{l}\text { Здатність підприємства ефективно розпоряджатися власними і позиковими ресурсами в умовах } \\
\text { конкурентного ринку. }\end{array}$ \\
\hline Р.А. Фатхутдінов [3] & Виробництво конкурентоспроможної продукції та стійка фрінансова діяльність. \\
\hline М. Портер [4] & Продуктивність використання підприємством окремих матеріальних та нематеріальних ресурсів. \\
\hline $\begin{array}{l}\text { П.С. Зав'ялов, Л.Ш. Лозовський, } \\
\text { А.Г. Поршнєв, Б.А. Райзберг [5] }\end{array}$ & $\begin{array}{l}\text { Здатність підприємства конкурувати на ринках з виробниками й продавцями аналогічних товарів за } \\
\text { допого забезпечення більш високої якості, доступних цін, створення зручних умов для покупців, } \\
\text { споживачів. }\end{array}$ \\
\hline
\end{tabular}


Як видно з табл. 1, поняття «конкурентоспроможність підприємства» провідні науковці визначають, у першу чергу, як здатність до ефективного використання наявних ресурсів, виробництва продукції, спроможної конкурувати на ринку. У визначенні, прихильниками якого є П.С. Зав'ялов, Л.Ш. Лозовський, А.Г. Поршнєв, Б.А. Райзберг, вбачається звуження поняття «конкурентоспроможність підприємства» шляхом ототожнення його із поняттям «конкурентоспроможність продукції». Якість, ціна, умови придбання є критеріями конкурентоспроможності продукції. Таке ототожнення може призвести до не вірних результатів оцінки рівня конкурентоспроможності підприємств, що має й інші показники та є значно ширшим поняттям.

Аналіз наукових літературних джерел дозволяє сформулювати визначення поняття конкурентоспроможність підприємств сільського зеленого туризму до реалізації наявних та потенційних виробничих, фінансових та управлінських можливостей ведення внутрішньо- і міжгалузевої конкурентної боротьби за цільових споживачів, ринкові частки шляхом раціонального використання власного майна, загальнодоступних місцевих природних та культурно-матеріальних цінностей як туристичних атракцій і надання послуг, орієнтованих на їх залучення.

Як свідчить вітчизняний і зарубіжний досвід, досягнення конкурентоспроможності таких підприємств забезпечується, перш за все, розробкою й реалізацією стандартів по розміщенню, харчуванню, трансферту й наданню якісних продуктів і послуг. У сукупності, це має забезпечувати задоволення попиту туристів та відпочивальників. Йому сприятиме впровадження нововведень (освоєння нових продуктів, послуг, атракцій, дестинацій, технологій їх здійснення, а також реклами, реалізації); удосконалення структури домашнього господарства, виробництва й управління, маркетингових стратегій; форм організації бізнес-процесів та взаємодії з постачальниками і партнерами, виходу на нові ринки тощо.

Конкурентоспроможність туристичного підприємства на селі визначається, перш за все, його здібністю до розвитку і можливістю виробляти товари і послуги, що відповідають вимогам галузевого ринку за умови якнайкращого використання всіх наявних ресурсів [6, с. 49]. При цьому вони мають бути більш прибутковими або привабливими з інших позицій відносно традиційних вже сільськогосподарських підприємств. Отже, досліджувана категорія має різні тлумачення в економічній літературі. Та, незважаючи на різні підходи до визначення суті поняття, можна визначають такі характеристики або індикатори конкурентоспроможності підприємств сільського зеленого туризму:

- відносний (порівняльний) характер - конкурентоспроможність проявляється тільки через порівняння характеристик підприємства 3 характеристиками інших суб'єктів даного або /та суміжних ринків;

- релевантний характер критерію конкурентоспроможності, який означає, що траєкторія руху даного підприємства (його конкурентна позиція) відносно інших суб'єктів може бути визначена тільки в межах релевантного зовнішнього середовища;

- часовий характер (динамічність) критерію конкурентоспроможності характеризує положення підприємства у конкурентному полі в координатах часу як результат його конкурентної діяльності;
- туристичні послуги можуть не співпадати у часі їх виробництва та надання;

- великий вплив на конкурентоспроможність мають чинники, які не завжди піддаються кількісному вимірюванню: гостинність, доброзичливість, виховання і такт, психологічна сумісність господарів і відпочивальників, специфрічні уподобання, суб'єктивні враження та оцінки.

Важливою передумовою формування конкурентоспроможності підприємств сільського зеленого туризму є визначення сукупності факторів, вплив яких може підвищувати та зменшувати ії загальний рівень. Крім того, аналіз факторів допомагає виявити сильні й слабкі сторони діяльності як самого підприємства, так і його конкурентів, розробити заходи щодо підвищення конкурентоспроможності [7, с. 78]. При цьому прискорення динаміки змін середовища функціонування підприємств сільського зеленого туризму вимагає постійного (перманентного) врахування факторів, які впливають на їх конкурентні позиції.

Усі фрактори з метою системного врахування й результативного використання з позицій конкурентних інтересів та переваг окремих підприємств доцільно поділити на дві групи: зовнішні, прояв яких меншою мірою залежить від їх власної організації та менеджменту; внутрішні, які практично цілком визначаються менеджментом, власниками, працівниками. Виокремлення саме таких фракторів $€$ логічним, оскільки для визначення конкурентоспроможності підприємств сільського зеленого туризму необхідно враховувати не лише процеси, що відбуваються в них, але й динаміку змін, що пов'язані із зовнішнім середовищем. Це необхідно для того, щоб своєчасно й адекватно реагувати на можливі ризики та загрози, використовувати переваги й ресурси або сприятливу кон'юнктуру ринку.

До найбільш суттєвих зовнішніх факторів впливу на конкурентоспроможність підприємств на внутрішньому ринку туристичних послуг слід відносити наступні: кількість конкуруючих підприємств на загальнонаціональному ринку та його територіальних складниках; державна політика підтримки та регулювання конкуренції та розвитку туристичного підприємництва на селі; простота входження в ринок; зміна темпів зростання ринку; обсяги й динаміка пропозиції та попиту на туристичні продукти і послуги; ступінь диференціації туристичного продукту; рівень розвитку підприємництва у сфері туризму; стабільність соціально-економічної та військово-політичної ситуації, екологічної та інших видів безпеки на окремих територіях і в країні загалом.

Специфічними фракторами впливу на конкурентоспроможність підприємств на внутрішньому та міжнародному ринках є: унікальність туристично-рекреаційних ресурсів, геополітичне положення країни, політична стабільність та екологічна безпека в регіоні, співвідношення курсів валют приймаючої та відправляючої країн, митне законодавство, традиції гостинності [8, с. 238]. Проведений аналіз факторів конкурентоспроможності надає можливість дослідити та проаналізувати насамперед внутрішні умови функціонування підприємств в Україні, виявити основні з них. Це дозволить окреслити загальні проблеми та шляхи їх подолання у сфері функціонування підприємств сільського зеленого туризму.

Конкурентоспроможність - це відносна характеристика, яка відображає відмінність від товару чи послуги конкурента, по-перше, за ступенем відповідності одній і тій самій суспільній потребі; по-друге, за витратами на задоволення

Вісник Сумського національного аграрного університету 
цієї потреби. Під витратами розуміють ціну споживання, включаючи витрати покупця, пов'язані з придбанням товару, і всі витрати, які виникають при його споживанні.

Забезпеченню конкурентоспроможності підприємств сільського зеленого туризму сприяють: управлінські рішення про вихід на нові ринки збуту або їх сегменти; реорганізація структури й організації діяльності; зміни господарських зв'язків і маркетингових стратегій навіть включно до формування брендів тощо. Ринкові відносини диктують підприємствам чіткі кінцеві цілі успіху в конкурентній боротьбі: максимальні прибутки при мінімальних витратах, задоволення запитів споживачів і перетворення їх на постійних клієнтів, високий рівень ефективності виробничо- та соціально-економічної діяльності. Реалізація цих цілей полягає у віднайдені і використанні конкурентних переваг, які забезпечують досягнення міцних конкурентних позицій й джерел їх підвищення.

Конкурентоспроможність підприємств сільського зеленого туризму означає, отже, їх здатність ефективно використовувати свій потенціал, спрямований на успішний комерційний результат за дотримання умов збалансованого розвитку сільських територій. Конкурентні переваги - це такі характеристики чи властивості, які забезпечують господарству або підприємству преференції над прямими конкурентами. У цьому процесі у даному випадку велике значення має думка односельців, сусідів, сприяння або лояльне відношення сільської громади загалом [9, с. 26]. Основними чинниками, які забезпечують конкурентні переваги, $€$ наступні:

- стандартизація та відмінна якість, що являє собою підвищену цінність для покупців або через зменшення їх витрат, або у зв'язку із підвищенням ефективності продуктів і послуг. Така зовнішня конкурентна перевага забезпечує туристичному підприємству підвищену ринкову владу, тобто може примусити ринок платити більш високу ціну;

- витрати підприємства нижчі за рахунок високої продуктивності. Така внутрішня конкурентна перевага робить підприємство прибутковішим;

- фахові навички, унікальні атракції чи технології, які створюють унікальну цінність для споживачів.

Конкурентні переваги підприємств сільського зеленого туризму за джерелами їх виникнення можна поділити на внутрішні і зовнішні. Внутрішні - це характеристики внутрішніх аспектів діяльності (рівень витрат, продуктивність праці, організація бізнес-процесів та, в кінцевому рахунку, найкращих умов для туристів тощо), які перевищують аналогічні характеристики пріоритетних конкурентів. Внутрішні переваги $є$ базисом загальної конкурентної переваги суб'єктів господарювання. У більш широкому розумінні вони визначаються як такі: виробничі (продуктивність праці, економічність витрат, забезпеченість матеріально-технічними ресурсами); технологічні (сучасність, гнучкість технологічних процесів, використання досягнень науково-технічного прогресу, соціальних нововведень); кваліфрікаційні (професійність, активність, творчість власників і працівників, схильність до нововведень, любов до своєї роботи і до людей).

Також це організаційні переваги (стандартизація, раціональність, структурованість, гнучкість, безпека); управлінські (ефективність і результативність управління якістю, закупівельними та збутовими процесами; мотивація і стимулювання працівників і власників); інноваційні (впровадження нових технологій, продуктів, послуг, наявність і впровадження ноу-хау, власні нові розробки); наслідкові (ділова етика й культура підприємства, його імідж, корпоративні традиції, родинні, місцеві й загальнонаціональні цінності); економічні (платоспроможність, ліквідність, прибутковість, рентабельність); територіальні (розміщення, близькість до джерел матеріальних і людських ресурсів, унікальних туристичних атракцій і дестинацій, транспортних шляхів та каналів розподілу, споживачів, територіальна доступність і комунікації).

Зовнішні конкурентні переваги базуються на спроможності підприємств створити більш значимі цінності для споживачів їх продуктів, товарів і послуг [10, с. 35]. Це створює можливості більш повного задоволення споживчих потреб, зменшення витрат чи підвищення ефективності діяльності. Зовнішні конкурентні переваги орієнтують підприємство на розвиток та використання тих чи інших внутрішніх переваг та забезпечують йому стійкі конкурентні позиції, оскільки направляють на цілеспрямоване задоволення потреб конкретної групи споживачів. Серед них важливе значення має рівень підтримки сільських територіальних громад, місцевих та національних органів влади, адже організація туристичної діяльності є абсолютно новим видом зайнятості для сільських жителів.

До зовнішніх конкурентних переваг підприємств сільського зеленого туризму можна віднести, насамперед: інформаційні (ступінь їх поінформованості про стан і тенденції розвитку ринку, дію сил і умов навколишнього бізнес-середовища, поведінку споживачів, конкурентів, бюджетні й податкові преференції або ж їх відсутність); конструктивні (технічні характеристики продукції, послуг, дизайн, реклама); якісні (рівень якості продукції та послуг за оцінками споживачів); поведінкові (ступінь поширення концепцій маркетингу серед працівників щодо задоволення потреб споживачів конкретних цільових послуг, дестинацій, атракцій); кон'юнктурні (ринкові умови діяльності, конкурентне середовище, кадрове й ресурсне забезпечення, державне регулювання тощо ).

Також це переваги сервісні (рівень та якість послуг); іміджеві (загальні уявлення споживачів про підприємство та його пропозиції продажів, місця розміщення або дестинації, популярність, упізнаваність, бренди); цінові (рівень та можлива динаміка цін, акції, подарунки, бонуси, інші інструменти маркетингових стратегій); збутові (портфель замовлень, прийоми та методи пропозиції товарів і послуг продукції); комунікаційні (канали і способи поширення інформації про підприємство, наявність і використання зворотного зв'язку, у т.ч. у вигляді інтернет-відзивів, форумів, блогів звичайних туристів-споживачів та фрахових оглядачів і аналітиків). Також слід враховувати такий чинник конкурентоспроможності, як мода на ті або інші види відпочинку і туризму, туристичні місця, курорти, дестинації і навіть країни. Вона формується під дією як цілеспрямованого впливу PR-технологій і реклами власників туристичного бізнесу, так і під дією впливу еліт та масової думки.

Висновки. Отже, конкурентоспроможність підприємств сільського зеленого туризму визначається як здатність ефективно використовувати свій майновий, трудоресурсний та іміджевий потенціал, спрямований на отримання прибутків шляхом надання відповідних продуктів і послуг за умов дотримання екологічних та інших пріоритетів збалансованого розвитку сільських територій. Останнє є важливим чинником, 
оскільки власники агроосель у своїй діяльності використовують не лише власні можливості, але й загальнодоступні місця територій свого розміщення, які допомагають їм формувати напрями бізнесу, продукти та послуги.

Їх основними властивостями має бути відмінна якість, що являє собою підвищену цінність для покупців або через зменшення їх витрат, або у зв'язку із підвищенням споживчих властивостей. Така зовнішня конкурентна перевага забезпечує сільському туристичному підприємству підвищену ринкову владу, тобто може примусити ринок платити більш високу ціну. Внутрішня конкурентна перевага означає, що витрати підприємства сільського зеленого туризму є нижчими за рахунок високої продуктивності. Така внутрішня конкурентна перевага робить підприємство більш дохідним.

Йдеться про унікальні навички персоналу або/і власників, унікальні атракції чи технології, які створюють унікальну цінність для споживачів. Також вони формують зовнішні та внутрішні конкурентні переваги. Внутрішні - це характеристики внутрішніх аспектів діяльності (рівень затрат, продуктивність праці, організація бізнес-процесів тощо), які перевищують аналогічні характеристики провідних конкурентів. Зовнішні конкурентні переваги базуються на спроможності підприємств сільського зеленого туризму створити більш значимі цінності для споживачів їх продуктів та послуг.

\section{Список використаної літератури:}

1. Wint A. Competitiveness in small developing economies. Canada: University of the West Indies Press. 2003. URL: http://www.questia.com/PM.qst?a= 0\&d=104310446

2. Азоев Г.Л. Конкуренция: анализ, стратегия и практика: Центр экономики и маркетинга, 1996. 208 с.

3. Фатхутдинов Р.А. Конкурентоспособность организации в условиях кризиса: экономика, маркетинг, менеджмент. Издательско-книготорговый центр "Маркетинг", Москва, 2002. 892 с.

4. Porter M. Competition. USA: Harvard Business School Publishing Cooperation, 2008. URL: https://www.hbs.edu/faculty/Pages/item.aspx?num=184

5. Клименко С. М. та ін. Управління конкурентоспроможністю підприємства. К., КНЕУ, 2006. 527 с.

6. Мармуль Л., Романюк І. Потенціал конкурентоспроможності підприємницької діяльності у галузі сільського зеленого туризму. Вісник Бердянського університету менеджменту і бізнесу. 2017. № 1 (37). С. 47-50.

7. Ігнатенко М. Теоретичні засади та практичні напрями формування корпоративної соціальної відповідальності аграрних і харчових підприємств. Економіка АПК. 2015. №.1 С. 78.

8. Пеньковський В.С. Соціально-економічна сутність та значимість підприємств сільського зеленого туризму у моделях організації та розвитку сільських територій. Наукові праці Полтавської державної аграрної академії. Вип. 2(9). Полтава: ПДАА, 2014. C. $237-241$.

9. Романюк І.А. Стратегічне управління розвитком галузі туризму на засадах формування корпоративної культури туристичних підприємств. Вісник Бердянського університету менеджменту і бізнесу. 2016. № 2 (34). С. 24-27

10. Ігнатенко М.М., Мармуль Л.О., Сарапіна О.А. Соціально-економічний потенціал сільських територій як основа розвитку підприємств сільського зеленого туризму на засадах інноваційності. Економіка та менеджмент культури. № 2. 2016. C. 32-38.

Adamchyk 0.0., PhD student, Kherson State Agrarian University (Kherson, Ukraine)

Theoretical fundamentals of formation of competitiveness and competitive advantages of rural green tourism enterprises

The article defines the content of the category of competitiveness and establishes its features in relation to rural green tourism enterprises. It is established that they function not so much in the conditions of intra-branch, but so much inter-branch competition. For the Ukrainian countryside, it is more traditional and typical to operate any-sized agricultural enterprises that make a profit under almost any conditions on the basis of diversification of production. It was found that in such circumstances, the existing internal and external competitive advantages of rural green tourism enterprises should have additional support from rural communities, budget and tax preferences and other forms and instruments of state support. This will strengthen their competitive position in order not only to generate profits and meet the needs of consumers in recreation, but also increase employment and living standards of rural residents, reduce the production burden on the environment and solve environmental problems in rural areas, accelerate development of related industries and activities.

Key words: enterprises, agro-villages, rural green tourism, competition, competitiveness, competitive advantages, agriculture, state support, formation, rural territories, management, theoretical principles.

Дата надходження до редакції: 18.10 .2019 р. 